\title{
A Key to The Land of Cokaygne: Satire or Parody?
}

\author{
Bart Veldhoen ${ }^{1}$
}

Published online: 7 December 2016

(C) The Author(s) 2016. This article is published with open access at Springerlink.com

\begin{abstract}
The Land of Cokaygne, or parts of it, is often treated as a satire, although admitted to be characterized as a text that mixes different genres. My contention is that it is essentially a parody of monastic life, for which I adduce Bakhtin's theory of medieval parody. It is shown that satire is no more than a side effect, but never offers a satisfactory key to the actual scenes of the text, whereas parody (in Bakhtin's terms) underlies every element of the poem. Also the manuscript context corroborates the idea of parody. Another new element that I have introduced is a passage from an Old Irish text the Lebor Gabála Érinn, which offers some remarkably close parallels to the opening lines of The Land of Cokaygne and shows clearly how The Land of Cokaygne works as a parody. A final new point I introduce is a reading of the episode of the nuns as a parody of the sacrament of Confession.
\end{abstract}

Keywords Middle English verse $\cdot$ Satire $\cdot$ Parody $\cdot$ Paradise $\cdot$ Monastic life $\cdot$ Lands of Fair-Ease · Bakhtin

The Middle English The Land of Cokaygne (London, British Library, Harley 913, 3r6v) appears to have been written in Ireland ca. 1330 (Treharne 2010: 545). The 190-line poem is notoriously difficult to interpret for modern readers, mainly because it requires a detailed knowledge of monastic life, which is rare among present-day audiences. To recognize its generic key, such knowledge is indispensable. A reading of the poem as satire is problematic. Actual medieval monks' vices, weaknesses or follies may be shown up or hinted at; there can be no doubt that occasional satirical thrusts are found in the poem. Yet, the vehicle does not match the tenor which, in the case of satire, should be, in the authoritative words of Ben Jonson:

Bart Veldhoen

neophilologus@gmail.com

1 Leiden University, Leiden, The Netherlands 
When she would show an Image of the times,

And sport with human follies, not with crimes,

Except, we make'hem such by loving still

Our popular errors, when we know they're ill.

I mean such errors, as you all confess

By laughing, they deserve no less:

Which when you heartily do, there's hope left, then,

You, that have graced monsters, may like men.

(Ben Jonson, Every Man in His Humour, Prologue, 11. 23-30)

The Land of Cokaygne is certainly humorous, but instead of mocking vices or follies or shortcomings of the monks, the poem is playing with their monastic Rule and with their duties. It appears to be a travesty of monastic ideals (cf. Davenport 2004: 192).

Even literary historians who discuss the poem only briefly, such as Derek Pearsall and Piero Boitani, do not typify The Land of Cokaygne as satire. Pearsall (1977: 100-101) labels it as a "goliardic Utopia" and a "comic parody of the earthly paradise". Boitani (1982: 33) rounds off his paraphrase of the poem with: "in The Land of Cokaygne we see the culmination of a carefree and volatile form of humour, which is quite without force and satiric bitterness, but devastating all the same." Rather, as I shall argue, it is parody that consistently underlies every element of the poem. The Land of Cokaygne is not mocking affectations, as one would expect of satire. Satire, as defined by Ben Jonson, is not what binds the text together. I should like to demonstrate that parody, as described by Mikhail Bakhtin, is the 'vehicle' or medium that governs the text. The key, for me, is the verbal irony characteristic of parody: a burlesque play on words, creating a caricature. Bakhtin argues convincingly, as we shall see later, that parody played a particularly significant role in the historical context of medieval culture. The special medieval brand of parody is less accessible for the modern reader because the details of the world turned upside down by the parody are no longer readily recognized.

The problem of the genre-whether satire or parody —is, perhaps, best illustrated by considering two passages first. The first describes the monks at mass (Treharne 2010: 545-549):

Whan the monkes goop to masse,

Al be fenestres that bep of glasse

windows; are

Turnep into cristal brizt

To zive monkes more lizt.

Whan pe masses bep iseiid, have been said

And pe bokes up ileiid,

pe cristal turnip into glasse

In state pat hit raper wasse.

(11. 113-20)

put away

earlier on

This passage could be read as a satirical thrust at monks for whom the spiritual illumination that they receive from the divine service does not make a lasting impression. However, the fact that the change that the illumination should make has 
been transferred ('translated') from the service itself to the windows can hardly be seen as typical of the satirical mode. Inversion of cause and effect is comic, but ineffective for purposes of deriding affectations. On the other hand, parody could be intended, in this case of the lines from the hymn Veni, Creator Spiritus, which was an invariable part of the canonical hours of Matins and Lauds: "Ascende lumen sensibus/Infunde amorem cordibus" (Kindle Your light for our senses/Pour Your love into our hearts), or from the prayer: "Gratia Sancti Spiritus, illumine cor nostrum" (Illuminate our heart through the grace of the Holy Spirit) following the kyrie eleison at the Preparation for Mass (cf. the Roman Missal). In that case, it could well be a parody of a common practice of monastic life, rather than a mocking of some folly or vice. The next scene causes a similar problem:

pe yung monkes euch dai

Aftir met gop to plai.

Nis per hauk no fule so swifte

Bettir fleing bi pe lifte

Pan pe monkes, heiz of mode,

Wip har slevis and har hode.

Whan pe abbot seep ham flee,

bat he holt for moch glee;

Ak napeles, al peramang,

He biddip ham lizt to evesang.

pe monkes liztip noght adun;

Ac furre fleep in o randun.

(11. 121-32) each day

their meal

hawk nor bird

through the air

their

he considers that

in the middle of all that

alight for evensong

further; at random

There could be a satirical suggestion here of a violation of the monastic vows of obedience and of 'stabilitas loci' - not to leave the monastery without the abbot's permission-, as Thomas Hill (1975: 55) and Wim Tigges (1995: 98) have suggested. The other two vows, of poverty and of chastity, are also seen to be implicitly broken elsewhere in the poem by the description of the abundance in the monastery and by the dealings with the nunnery, respectively. The passage could also be read as a satirical mocking of monks not being inspired by spiritual, but by physical food: "Aftir met" (1. 122), so by gluttony. The punning association of Gula (gluttony) and Regula (monastic rule) was, after all, a wordplay that was very commonplace throughout the Middle Ages (Cartlidge 2003: 46-47).

Such wordplay would suggest a parodic/linguistic approach rather than a satirical one. Satire against monks' volatility might well be intended, but, as I have argued above, the 'vehicle' or medium is the kind of wordplay characteristic of parody: in this case a parody of the monastic ideal of contemplation. As Hill (1975: 57) reminds us, contemplation was known in monastic circles as 'volare ad Deum' (to fly towards God). "Heiz of mode" (in high spirits/in an elevated mood, 1. 125) would then be the giveaway marker for the parody, just as "to jive monkes more lizt" was, by the same token, in the previous scene (1. 116). We shall see later that there are similar markers for a parody-reading in the other passages as well. 
A reading as parody is also supported by the manuscript context. In his analysis of Harley 913, Neil Cartlidge points out that the codex contains a considerable number of texts of a parodic nature, among them a 'Drinkers' Mass', an 'Hours of the Seven Sleepers', and a 'Devil's Letter' (2003: 47-52). Cartlidge also notices a preoccupation with food, drink and feasting throughout the manuscript, commonly as absurd parodies of temperance (2003: 46). He argues that the Gula/Regula pun, mentioned above, underlies this preoccupation: in its parodic use it emphasizes the importance of temperance for living a Christian life according to a Rule.

For my conviction that the undoubted satirical effects are only occasional in The Land of Cokaygne, but that parody is the true medium of this text - the key to the interpretation of the whole poem-I am indebted to Mikhail Bakhtin's ideas about the importance of parody in the Middle Ages (Bakhtin, 2000: passim).

According to Bakhtin, the Middle Ages inherited from classical antiquity the idea that everything serious needs to have its comic double. He points to the Greek satyrplays following the tragedy-trilogies on the same themes on the stage and, more $a$ propos, to the Roman Saturnalia, festivities mixing the serious with original productions for laughter, often based on local folklore. Bakhtin sees these doubles as parodies liberating the serious from the power of language. The basis of his argument is that pre-Renaissance parody was much more important than it has been ever since. The "appropriation of words of others" (Bakhtin's definition of parody) was a central concern of the Middle Ages, he argues, because all the most important domains of official life-Holy Scripture, religion and political theory-had come down on the lay people in Latin and had to be appropriated by them in a process of 'translatio' (transfer) into their vernaculars.

The freedom-or perhaps one should say respected necessity-of expression in terms of parody was especially connected with feastdays and school festivals. The Feast of Fools or Feast of the Ass encouraged laughter in the church at Easter and Christmas, as a means to celebrate resurrection and rebirth by cheerful rather than reverentially serious means. Bakhtin mentions as a further instance that in the schools at the end of term everything that had been seriously studied was ridiculed, from Sacred Writ to school grammar-in the spirit of the satyr-plays. Parodies of hymns, prayers, even complete liturgies followed (such as witnessed in Harley 913).

Bakhtin reminds us that the sacred Latin word was a foreign body that had invaded the organism of the vernacular languages, conceptualizing the higher ideological thought-processes. He continues to state that the fact that this Latin imposed from above is "someone else's word" was felt as much in the reverent acceptance as in the parodic ridicule. He mentions as examples of the former the many macaronic texts, and of the latter the Carmina Burana. In the context of The Land of Cokaygne it is interesting to note that the Carmina include a song by an "abbas cucaniensis" (abbot of Cokaygne).

Apart from the "parodia sacra", Bakhtin points out, also "intentional hybrid" texts appeared, consisting of a cross-over of styles of discourse within the vernacular language. The values of the parodied style are transposed and biased in a particular direction. These are "dialogic texts", which Bakhtin sees as an argument between two 
generic languages within the same language, between two points of view which cannot be translated into one another. These are 'dialogues' between, on the one hand, a dismal sacred world of joyless pedants or unctuous hypocrites and a cheerful folk world, on the other. In the vernaculars, Bakhtin concludes, parody is a superstructure of laughter on the Roman model: the laughing double for each serious form, as Shakespeare's fools and clowns are, I should add, and, possibly, Rabelais and Cervantes.

Bakhtin's analysis of medieval parody appears to me to be eminently relevant to The Land of Cokaygne. Its picture of an upside-down world, like that of the Carmina Burana, is described by Bennett as a parodying style which "limits or sterilizes the satiric possibilities implicit in an account of the solid joys and liquid pleasures known to monks and nuns" (Bennett 1986: 14-15). It is possible to read Cokaygne's analogues as wish-fulfilments of a downtrodden peasantry, as Southern (1970: 230) and Hill (1975: 56) have suggested, but I do not see how this interpretation elucidates our particular poem in hand (cf. Bennett 1986: 17). Nor do I find in Cokaygne the kind of symbolism typical of romances and fantasies that creates extra dimensions of narrative space for allusive significations. I rather notice a limitation of significances by means of 'différances' (Lacan's term, 1966: passim) created by the language of the poem, so: an 'intentional hybrid' $a$ la Bakhtin, akin to the parody of sacred ceremony at the Feast of Fools.

The very opening of the poem, the 'translatio' of Paradise to the West, already appears to function as a comic double (Bakhtin), or as a 'comic antitype of Paradise', showing the goliardic impulse of those who lead a life of discipline to occasionally play the fool, as witnessed in the Carmina Burana (Bennett et al. 1966: 137-138). Bakhtin's argument that these 'translationes' of religious, political and scholarly data from Latin or otherwise 'from another world' have a historical function for the common people to learn the languages and terminology in order to fully understand and integrate the concepts, is a key to The Land of Cokaygne that really unlocks its topsy-turvy world. It is this same argument that also applies to the comic 'translations' in the later Mystery Plays, and in Shakespeare's clowns and fools, as I mentioned earlier, just showing how important-and 'likely' — this type of intentional hybrid parody was for the Middle Ages.

That Cokaygne's particularly sensual paradise in the West is, first and foremost, a parody of the spiritual paradise (Hill, 1975: 56) or of the monastic ideals, is borne out clearly enough by a detailed analysis of the text. The satirical implications are no more than natural side-effects of such a parody, not the core of the form. The Land of Cokaygne is localized explicitly in the Atlantic Ocean west of Spain:

Fur in see bi west Spayngne

Is a lond ihote Cockaygne:

per nis lond under hevenriche

Of wel, of godnis, hit iliche.

Po3 Paradis be miri and brizt,

Cockaygn is of fairir sizt. (11. 1-6)
Far into the sea

called

there is no

Its peer in

The fact that Cokaygne is presented as superior to the Earthly Paradise is subsequently illustrated by a wealth of strictly sensual details: richer food, better 
lodging, absense of labour, strife, noxious animals and bad weather (11. 7-44). Like Thomas Hill and Wim Tigges, Emily Yoder uses this fact of Cokaygne's geographical position west of Spain to point to St Brendan's Island of Promise or Fortunate Isle as also situated in the Atlantic Ocean (south-)west of Spain (Yoder 1983: 235 et passim), concluding that The Land of Cokaygne belongs to the tradition of the Navigatio Sancti Brandani. Yoder does so with less suggestion of parody than either Tigges or Hill, who are referring to a much wider and, presumably, older tradition, especially in Ireland, of Blessed Isles in the West. The ancient Greeks, by the way, had also located their Elysium in the West beyond the Pillars of Hercules. It would appear that in pre-Christian times notions such as regions of the rising or the setting sun, or places as far away as possible from one's own world, have contributed to the allocation of places of reward for the deserving. The tradition seems to be rather more complicated than has been brought to bear on our poem. Moreover, the popular descriptions of the Earthly Paradise in the East also tend to concentrate on the physical luxuriance of the Garden of Eden rather than on the special pre-lapsarian spiritual grace. It is as if Bakhtin's notion of parody was already at work here from the start: to convey the spiritual ideal through the sensual.

I have found one authoritative text among the more ancient Irish 'historical' texts that has not, to my knowledge, been mentioned in connection with The Land of Cokaygne. It seems to me to offer a more convincing source than the Blessed Isles texts, because it contains more details directly corresponding to Cokaygne than just its geographical position. It is the Lebor Gabála Érenn: The Book of the Taking of Ireland, which in its Sect. 101: "An explanation of the Takings of Ireland" (in Old Irish) describes Ireland first in Latin ${ }^{1}$ :

The island of Ireland is situated in the west; as the Paradise of Adam is situated on the southern coast of the east, so Ireland is in the northern portion, toward the west. Those lands are as similar by nature, as they are similar by their positions on the earth: for as Paradise hath no noxious beasts, so the learned testify that Ireland hath no serpent, lion, toad, injurious rat, dragon, scorpion, nor any hurtful beast, save only the wolf. And so Ireland is called "the island of the west" ... This [Hibernia] stretches northward from Africa, and its foremost parts tend towards Iberia (that is, Spain) and the Bay of Biscay; whence also Hibernia takes its name .... Within it is no serpent, rare bird, nor bees; .... .

The absence of noxious animals, as listed in the Lebor Gabála Érenn, features prominently in The Land of Cokaygne, too. (11. 31-44). There are striking similarities-both mention serpents first in the list-but also striking differences: the absence of the wolf is mentioned second in Cokaygne, whereas the wolf is the only noxious animal that is not absent in the Lebor Gabála. Nor does Cokaygne make the point that the absence of those noxious beasts is similar to their absence from Paradise. The other animals in Cokaygne are strikingly different: fox, horse,

\footnotetext{
1 Stewart MacAlister, 1932: 165. MacAlister gives the Third Redaction of Sect. 101, which is in Latin from "Ut dixit historia" (162) onwards, from an originally independent 'Liber Occupationes', in which elements from Isidore of Seville, Orosius and Nennius have been interpolated. Extant manuscripts are sixteenth-century, based on sources from the twelfth century.
} 
nag, cow, ox, sheep, swine, goat, studs, fly, flea, louse, worm and snail; some of these are hardly noxious, and some of them appear to be there merely for rhyming purposes. It would seem that Cokaygne's list rather functions as comic hyperbole for the purpose of parody.

If The Land of Cokaygne parodies the Lebor Gabála or its sources for its opening description, its parody is a multiple one: not only do we have the 'translatio' of extreme geographical positions from one end of the world to its diametrically opposed position, but Cokaygne becomes a parody of Ireland, itself 'historically' seen as a type of Paradise ("ut dixit historia"). Blessed Isle, indeed!

Cokaygne's claimed superiority to Paradise is stressed by claiming that Paradise is "elinglich" (15: a miserable place) since it has but two inhabitants, Elijah and Enoch (13-14). As in the case of the triple parody of Cokaygne = Ireland = paradise, the lack of company in Paradise is particularly ridiculed by playing on the medieval meaning of 'paradisus' as either the Earthly Paradise (Vulgate trsl. of Genesis's 'Garden of Eden') or Heaven (Luke 23:43; 2 Corinthians 12:4). Enoch (Genesis $5: 24$ ) and Elijah (2 Kings 2:11) were taken up bodily into Heaven, specifically not to the Earthly Paradise, the obvious referent of Cokaygne (cf. Bennett 1986: 16). This complex play on 'paradise' seems to be parody to be enjoyed by an informed audience.

A similar double parody is found again with the four rivers "of oile, melk, honi, and wine" (45-46) in Cokaygne, which make Cokaygne a pleasanter place than Paradise where there is only "water manis thurst to quench" (12). This detail of the four rivers in Cokaygne parodies the four rivers of the Earthly Paradise of Genesis, but adds the specifics of oil, milk, honey and wine as found, for instance, in the eighth-century Visio Pauli (cf. Bennett et al. 1966: 338, commentary on 1l. 45-46). The same happens later on with the four wells in the monastery in Cokaygne, the specification of which (healing ointment, healing water, balm, spiced wine; 83-85) derives from the twelfth-century tradition of St Patrick's Purgatory (Bennett 1986: 16). Both the four rivers and the four wells in The Land of Cokaygne belong to the tradition of visions of heaven rather than of the earthly paradise. Undeniably rich parody.

When we come to the description of the monastery in Cokaygne, my point about The Land of Cokaygne being essentially a parody of the ideal standard of monastic life comes up for the test. The external description of the monastery (11. 51-112) is a classic hotch-potch of elements of traditional and popular paradise-descriptions, such as the Tree and the rivers of Genesis and the precious stones of Revelation, and the foodstuffs and spices as building-materials and the ready-baked birds flying into the monks' mouths from the rich tradition of the lands of Fair Ease, made comic here by strikingly hyperbolic detail. To see that this wealth of detail is serving the purpose of parody, Hill's reminder that the cloister of a monastery is traditionally called 'paradise' by monks ('paradisus claustralis') is particularly relevant. Monks do not only lead a monastic life in order to obtain Paradise, but they see the secluded and well-regulated monastery as one, and even call their cloister by that name (Hill, 1975: 56). Cokaygne's monastery as 'translatio' of Paradise is really linguistic parody. 
The first two action-scenes in the monastery have already been discussed in the opening pages of this paper. For the scene of the mass I postulated a parody of the Veni, Creator Spiritus, of the Matins and Lauds, or of the common prayer at the Preparation for Mass, suggested by 1. 116: "to jive monkes more ligt". Moreover, for the scene of the flying monks I followed Hill's suggestion that the monastic ideal of contemplation, a flight of the soul or spirit known as 'volare ad Deum', is parodied, as suggested by 1. 125: "the monkes, heig of mode". The scene then continues:

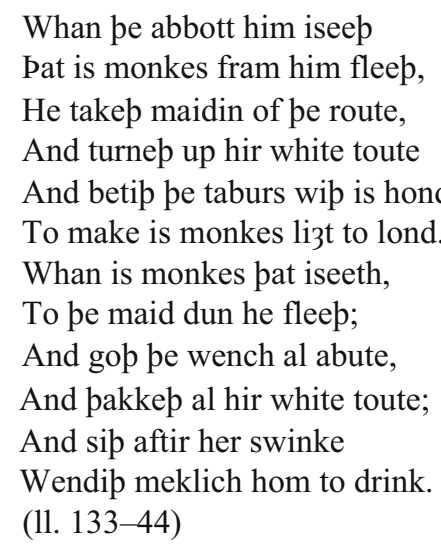

sees them
his
a girl from the crowd
buttocks
beats the drums
come down to earth
down; they
around
all thwack
then; their labour
go; meekly

Hill (1975: 58) notices that the beating of the girl's "white toute" to call back the monks from their flight must be the abbot's way of pulling the monks out of their contemplative state back to an awareness of physical reality, but he has nothing to say about the amazing image itself. P. L. Henry had a sharper eye for detail here: he considers the juxtaposition of the "white toute" (142) and "swinke" (labour) in the next line as an allusion to the Benedictine and Cistercian Rule of 'ora et labora' (pray and work), which refers to the monks' duties to alternate prayer with physical labour, usually in the fields. More specifically Henry refers to the traditional monastic wake-up call 'pulsatio tabule', beating a tabletop with two hands to wake up the monks in the morning (Henry, 1972: 136). He calls it "part of the satire", but it appears to me to be, rather, another instance of aspects of the ideal standard of monastic life being parodied here, with "swinke" as the giveaway marker for parody and the 'translatio' of the morning wake-up call to the evening meal ("collacione", 1. 145) as another parodic device of the Gula/Regula type.

The next action-scene involves the nuns in a nearby abbey, apparently luring or inviting the monks to them for 'play'. On hot days the nuns go out on a "river of sweet milk" (149), where they "makip hem naked" (156: bare their bodies) to have a swim "sleilich" (158: stealthily). When the monks spot them, they "dop ham up" (160: make themselves ready). Next, each monk takes a nun and "techip pe nunnes an oreisun/Wip jambleve up and dun" (165-166: teach the nuns a prayer with legs raised up and down). If a monk is a "good stallion" (167), he shall have twelve 'wives' each year "al pro3 rigt and not pro3 grace" (171: all by right and not through grace) for his comfort. 
About the "river of milk" Thomas Hill remarks that in the Visio Pauli, which may have provided the specification of the four rivers, the 'well of milk' is a chastitywell in which 'fornicatores' and impious souls are purified (Hill 1975: 58). In the context of the monks' fornication, the river-of-milk parody of the Visio Pauli may well have a satirical tenor. However, if one assumes that parody as the vehicle for the whole poem refers to the routines of ideal monastic life, it follows that it is the purification rather than the fornication that is operative here. The fact that the context in Cokaygne contains a number of other markers warrants the conclusion that what is parodied in this scene is actually the sacrament of confession. Nunneries depend on regular visits of priests for saying daily mass, for spiritual guidance of the nuns and for administering the sacrament of confession. The latter would be done on a monthly basis, which might explain why in Cokaygne the monks "shal hab wipoute danger/xii wives euch yere:/Al pro3 rizt and not pro3 grace (169-171: shall have without difficulty twelve women every year, by right and not through grace). Bennett (1986: 17) pointed out already that 1. 171 should be recognized as a parody of theological language, making the possibility of satire rather unlikely. However, he did not specify the implications, nor has anyone else so far, to my knowledge. To me, it appears to be part of the parody of the nuns' monthly confession. This idea is further marked by the nuns 'baring their bodies' (156), parodying the proverbial expression 'baring one's soul' popularly used for confession. The monks 'making themselves ready' (160: "dop ham up") would then parody putting on the special stole that priests must wear for the hearing of confession. The "oreisun" (165: prayer) they teach the nuns then refers to the penance imposed after confession. Praying was commonly performed with arms raised in pre-feudal times, and later still by those in holy orders. Kneeling down with hands folded-a ritual borrowed from feudal homage - was only gradually taken up in the Middle Ages (Cook and Herzman 2004: 174). The raised arms are parodied in Cokaygne by the "jambleve" (raised legs) of 1. 166.

Using sex as a parody of the sacrament of confession appears to foreground the regenerative power of confession by presenting it as a generative action; another example of parody based on wordplay. The monks are presented as having to be "stalun gode" (167: good stallions). Even for the non-participant "pat slepip best,/ And dop his likam al to rest" (173-74; because he is getting too old for sex?), there is hope to be a generator yet as "vadir abbot" (176; Father). Bennett (1986: 16) also appears to detect parodic play on spiritual regeneration when he explains the emphatic mention of 'studfarms and studs' (35) among the noxious animals absent from Cokaygne as being compensated for by the monks acting as 'good stallions': the (re)generative power of priesthood, as opposed to the noxious studs.

The idea of penance also dominates the final description of how to enter the Cokaygne-paradise (177-end). The traditional barrier to a land of Fair Ease is specified in The Land of Cokaygne as wading through pigs' dung for seven years, which is a "ful grete penance" (178), indeed. This barrier parodies the church's teaching that the heavenly paradise can only be entered after penance on earth, or else in purgatory. Treharne's suggestion (2010: 545) that the pigs' dung has possibly been borrowed from non-orthodox homilies, in which standing eternally in dung constituted a punishment of one hell set aside especially for liars, may add a final 
parodic inversion, telling us that the author is speaking the truth, because he himself has not been stuck in the dung. Similarly, Dante's punishment of flatterers by being stuck in dung (Inferno, XVIII) might also come to mind, with comparable effect. Anyway, we are, apparently, not to take the poem seriously, that is: not as a didactic-mocking satire. It is, instead, a topsy-turvy presentation of a serious way of life, very much in the mode of the Saturnalia and of Bakhtin's 'intentional hybrid' medieval parodies. Seeing that parody is consistently at the basis of every detail of the poem and that satire cannot be said to be more than an occasional effect, I opt for parody as the 'genre' of the poem, if the poem must have a generic label and if Marshall McLuhan's famous dictum that "the medium is the message" applies at all.

Open Access This article is distributed under the terms of the Creative Commons Attribution 4.0 International License (http://creativecommons.org/licenses/by/4.0/), which permits unrestricted use, distribution, and reproduction in any medium, provided you give appropriate credit to the original author(s) and the source, provide a link to the Creative Commons license, and indicate if changes were made.

\section{References}

Bakhtin, M. (2000). From the prehistory of novelistic discourse. In L. David \& W. Nigel (Eds.), Modern criticism and theory: A reader (2nd ed., pp. 104-136). London: Longman.

Bennett, J. A. W. (1986). Middle English literature, edited and completed by Douglas Gray (p. 1990). Oxford: Oxford University Press.

Bennett, J. A. W., \& Smithers, G. V. (Eds.). (1966). Early Middle English verse and prose (p. 1968). London: Oxford University Press.

Boitani, P. (1982). English medieval narrative in the thirteenth and fourteenth centuries. Cambridge: Cambridge University Press.

Cartlidge, N. (2003). Festivity, order, and community in fourteenth-century Ireland: The composition and contexts of BL MS Harley 913. The Yearbook of English Studies, 33, 33-52.

Cook, W. R., \& Herzman, R. B. (2004). The medieval world view: An introduction (2nd ed.). New York/ Oxford: Oxford University Press.

Davenport, T., (2004). Medieval narrative: An introduction. Oxford: Oxford University Press.

Henry, P. L. (1972). The Land of Cokaygne: Cultures in contact in medieval Ireland. Studia Hibernica, 12, 120-141.

Hill, T. D. (1975). Parody and theme in the Middle English 'Land of Cokaygne'. Notes and Queries, 220, $55-59$.

Lacan, J. (1966). Écrits. Paris: Édition du Seuil.

Pearsall, D. (1977). Old English and Middle English poetry. London: Routledge \& Kegan Paul.

Southern, R. W. (1970). Western society and the Church in the Middle Ages. Harmondsworth: Penguin.

Stewart MacAlister, R. A., ed. \& trans., Lebor Gabála Érenn: The Book of the Taking of Ireland, Part I. Dublin: Irish Text Society XXXIV (1932) 1938.

Tigges, W. (1995). The Land of Cokaygne: Sophisticated mirth. In N. H. G. E. Veldhoen \& H. Aertsen (Eds.), Companion to Early Middle English literature (2nd ed., pp. 93-101). Amsterdam: VU University Press.

Treharne, E. (Ed.). (2010). Old and Middle English c. 890-c. 1400: An anthology (3rd ed.). Oxford: Wilery-Blackwell.

Yoder, E. K. (1983). The monks' Paradise in The Land of Cokaygne and the Navigatio Sancti Brandani. Papers on Language and Literature, 19, 227-238. 